\title{
Family Business Succession: Does Experience Gained in Family Firm Really Count?
}

\author{
PREDRAG LJUBOTINA \\ Slovenia \\ predrag.ljubotina@gmail.com \\ JAKA VADNJAL \\ University of Ljubljana, Slovenia \\ jaka.vadnjal@gmail.com
}

\begin{abstract}
Potential family business successors have to resolve a complex trilemma when choosing their career path. Instead of choosing between the entrepreneurship and employment, they have to consider family business succession as an additional option. GUESs 2014 survey, conducted among more than 109.000 students in 34 countries, offered us the possibility to investigate the correlation between successors' career choice intentions and personal motives, family business experience and individual entrepreneurial skills. We analysed the data using multinomial logistic regression since career decision is measured as a categorical dependent variable with three possible solutions. We founded a significant correlation between personal motives and career decision. Similarly, the age at which potential successor was engaged in family business activity significantly influences his or hers career choice intention. On the other hand, we found that the length of engagement is not a significant factor. The higher level of self-assessed entrepreneurial skills is working in favour of succession when compared with employment option.
\end{abstract}

Key words: Family business, succession, career decision, skills, entrepreneurial education, feelings

https://doi.org/10.26493/1854-4231.13.301-322

\section{Introduction}

Family business vision of long term, trans-generational growth of family firm and wealth, is the main distinguishing factor between family and nonfamily firms (Zellweger et al. 2012). Succession process appears to be one of the most important issues for assuring that growth from the viewpoint of continuation and sustainability of the on-going business. We know several different cases, which show us that it is very hard to predict family business future. We heard for 
Kong' Gumi, a factory, which was absorbed by a multinational company in 2006 after successfully running the business within the family for about 1.400 years. On the other hand, we know that only one third of family firms survive the first transition and poor $10 \%$ the second nowadays (Le Breton-Miller, Miller, and Steier 2004). There are many reasons for that and they vary substantially with time, personal values and environment. That is why continuous research in the field of succession proves to be fundamental for the theory and practice of family business.

Successors, without any doubt, have and should continue to have one of the main roles in transition processes. They are usually confronted with a specific trilemma when deciding for the future career path, since they have an additional option comparing to their peers. They can seek for a job, start a new venture as an entrepreneur or take the responsibility for family firm future as a successor, both in the role of manager and/or future owner of the business. Previous studies identified various factors influencing the potential successor's career decision process. However, there are several gaps in deeper understanding the career intention of family business heirs. There is a traditional belief that they will join the family business and, sooner or later, take it over.

Still, potential successor is confronted with very hard decisions when it comes to choosing the career path. Today, young people are overexposed to many socio-economic factors in dynamic and constantly changing environment. In the parallel, they are frequently confronted with the lack of parental influence, due to lack of time. Given the importance and economic relevance of family businesses for any national economy, it is crucial to understand the communication gap, which results from described situation. This challenging topic was addressed by some recent papers which investigated several determinants of potential successor's career choice intentions (De Massis, Chua, and Chrisman 2008; Zellweger, Sieger, and Halter 2011; Altinay et al. 2012; Claire and Perryman 2016; Farrukh et al. 2017; Murphy and Lambrechts 2015). Young people are an important part of human capital in the country or in the business. Since human capital consists of knowledge, education, qualifications and skills it is created through education and improving professional skills, with consideration of work culture, psychological characteristics and physical conditions (Dorożyńska and Dorożyński 2015).

Our research has an ambition to build the multilevel model with the goal of explaining and predicting career choice intention based on important individual motives, experience in family firm and self- 
assessed entrepreneurial skills. We rely on a massive database from the international GUESSS 2014 (Global University Entrepreneurial Spirit Students' Survey) survey which allowed us to test the model on multinational level. Our main purpose is to test the influence of family business experience on heir's career decision taking into account personal motives and entrepreneurial skills perception. The study provides a better insight into the family business dynamics and intra-family relations in the context of succession process. We also base our study on recent calls for additional research focused on broader understanding of the area specially employing multicountry samples and considering type of business to be started (e.g. new own business or family business in our case) (Zapkau, Schwens, and Kabst 2017).

\section{Theoretical Background}

Family business tends to be a very volatile structure based on two important systems: family and business. These two systems have different boundaries, rules and individual roles but they are still interconnected. The inclusion of family and family members' relations makes family businesses different when compared to nonfamily owned firms (Eddleston, Kellermanns, and Sarathy 2008). Previous researches confirmed that there was a significant correlation between family and family business. Family business which gives more to family and business duality and correlation has better family and business results (Basco and Rodríguez 2009). Family support by itself significantly influences children's entrepreneurial intention (Shen, Osorio, and Rutgers 2017).

Each family member's identity is partly defined by his relationship with the family business (Kleiman and Peacok 1996). This relationship may be influenced by many different personal, business, environmental or economic factors. Several impacting factors are found to influence the family business transition process in the time gap between heir's education and career decision making. Some of such factors are: social capital, gender, economic situation, historical background, personality, attitudes, experiences and parental role model (Tarling, Jones, and Murphy 2016). Family business background has a positive impact on entrepreneurial intentions (Farrukh et al. 2017). Children with entrepreneurial parents are more inclined to follow an entrepreneurial career (Carr and Sequeira 2007). Next generation family members need to find balance between their own personal career interests and aspirations, family interests and orientations and employment opportunities (Schröder and Schmitt- 
Rodermund 2013). In this position, family business long-term well being may prevail over their personal career preference (Murphy and Lambrechts 2015).

Parents as role models provide opportunities for their heir's to learn from their experiences (Bandura 1977; Altinay et al. 2012). They can also alter the learning environment and increase entrepreneurial motivation among their children. Individuals are believed to gravitate towards the role models with the goal of gaining higher level of knowledge and skills (Gibson 2004). Previous research confirmed that student whose parents have started a family business and have been successful, have a significantly higher entrepreneurial intentions, compared to their peers (Ozaralli and Rivenburgh 2016). Early exposure to parental role models, which is an everyday common situation in family business, positively influences children's attitude towards self-employment (Chlosta et al. 2012). Parental entrepreneurial role models and positive family business experience generally nurtures the heir's self-confidence and reduces traditional fear from failure (Bosma et al. 2012). It also significantly increases heir's entrepreneurial ambitions (Altinay et al. 2012). Beside business related knowledge, entrepreneurial family members equip potential successors with business skills necessary for successfully running the family firm (Nicolau et al. 2008). Still, we have to mention that other researchers did not encounter any positive correlation between heir's exposure to family business and attitude towards self-employment (Kim, Aldrich, and Keister 2006). Novel studies of the specific field are obviously necessary. Researchers already called for further exploration of family dynamics influence on family member's career decision making (Aldrich and Cliff 2003).

Another key factor in encouraging entrepreneurship is awareness of entrepreneurs in local community. Recent studies showed that student population is decidedly unaware of their local entrepreneurial community (Claire and Perryman 2016). This finding is particularly important for college students who are in critical phase of forming their career decision. Active involvement in family business surely contributes to this awareness. Previous studies found that family members are most strongly involved as young individuals (Klyver 2007). Entrepreneurial education is another contributing factor in this context since it influences entrepreneurial intentions mostly indirectly through improving students skills, need for achievement, risk taking propensity, creativity and other entrepreneurial characteristics (Kusmintarti et al. 2016). 
In our research we focused on personal traits processed in GUESss 2014 study, which could partly be shaped by the family-business relationship and heir's exposure to family business. Personality traits are known to be relevant factor for entrepreneurial intentions (Ozaralli and Rivenburgh 2016). Our paper contributes to the research in the field of family business succession by investigating a specific group of students with family business background and by modelling their career decision with the desire for independency, entrepreneurial skills and exposure to family business. We designed two models for two different time periods. Relaying on the results of previous studies, which confirmed that family members want to learn from family firm before starting their own business (Tarling, Jones, and Murphy 2016), we observed heir's career choice immediately after their studies and five years after that. This approach is appropriate having in mind that based on actual career decision research, potential successors who put their own career on hold at the cost of helping family business, fulfilled their goals at later stage of life (Murphy and Lambrechts 2015).

Helping the family inevitably shortens the time spent outside family and family firm. Consequently, adolescents spend less time socializing with their peers. On the other hand, these adolescents can develop important entrepreneurial and general life skills and establish themselves as valued members of society (Fuligni and Telzer 2013). The sense of obligation to the family has implications in adulthood which makes potential heir's decisions more difficult. This naturally engrained act of helping the family is very specific in the context of family firm. It differentiates potential successors from their peers and is still relatively unexplored (Murphy and Lambrechts 2015).

\section{Hypotheses Development}

Among Kolvereid's (1996) factors which are motivating individuals for self-employment (economic opportunity, autonomy, authority, challenge, self-realization and participation in process), we detected two personal factors, which may be shaped by family relations. Those are autonomy and self-realisation. Both factors are important motivators, frequently given as a reason for starting a new venture (Kolvereid 1996). People often start businesses to achieve autonomy. Almost all small business starters expose autonomy as an important factor for their career decision. The firm could be seen as an instrument for achieving that goal (van Geldern and Jansen 2006). Even more, some studies control groups which con- 
sisted of non-entrepreneurs, also gave same value to autonomy as nascent entrepreneurs (Carter et al. 2003). Self-realization, as another influencing factor, is understood as the pursuit of goals that are of interest to the entrepreneur (Edelman et al. 2010). Selfrealizer is a person who lives creatively and fully uses his potential (Maslow 1954). This definition was also adopted and used in previous research where it was interpreted as transformation of opportunities into the reality (Maksimenko and Serdiuk 2016). Acting on the basis of self-realization values is influenced by feeling of personal expressiveness. As such, self-realization contributes to intrinsic motivation and is correlated with perceived competence (Waterman et al. 2003). Self-realization is also linked with the need for self-improvement or achievement and represents an important motive for entrepreneurial behaviour (Barba-Sánchez and Atienza Sahuquillo 2012). The need for achievement is one of the most powerful motivational factors within the domain of personal traits related to entrepreneurship (Altinay et al. 2012). Previous studies confirmed that significantly more start-ups are realized by individuals whose valence for entrepreneurial career is based on self-realization rather than financial success (Renko, Kroeck, and Bullough 2012).

$\mathrm{H} 1$ Higher level of perceived importance of autonomy result in preferring founding own new business over the succession and succession over the employment (Kolvereid 1996; van Geldern and Jansen 2006).

н2 Higher level of perceived importance of self-realization result in preferring founding own new business over the succession and succession over the employment (Kolvereid 1996; Waterman et al., 2003).

Entrepreneurs often share family business background. Prior family business experience affects future generations in many ways (Dyer 1992). Their entrepreneurial attitudes and behaviours may be positively or negatively shaped towards business ownership (Carr and Sequeira 2007). Parental work experiences for example, have significant influence on children. These influences may be internalized in a form of norms or children's future behaviour (Menaghan and Parcel 1995). Some previous pieces of research correlate these findings with family business, namely by confirming that early exposure to entrepreneurship and experience in the family business will affect family member's entrepreneurial intentions and attitudes in the future. Many entrepreneurs confirmed their prior direct exposure to family business in their young age (Dyer and Handler 
1994). Early socialization in a family business is recognized as an influential factor, which influences the formation of individual's entrepreneurial values and attitudes (Light and Bonachich 1991). Early exposure to family business also builds positive entrepreneurial values and beliefs which are lasting and impacting (Tarling, Jones, and Murphy 2016). Potential successors are involved with the family business in their young age through the activity of helping. This represents an important part of their career exploration during childhood which further relates to exploratory behaviour during adolescence (Murphy and Lambrechts 2015). Length of exposure to family business (working for family firm) may as well be a significant influential factor when time comes for a career decision (Morris, Williams, and Nel 1996). Since career exploration is related to career decision making, family members who are involved in family business for a long period of time, without exploring other career opportunities, may limit their choices in critical period (Schröder and Schmitt-Rodermund 2013).

н3 Older the heir is when exposed to family business for the first time higher is the preference for employment or founding own new business over the succession (Dyer and Handler, 1994).

$\mathrm{H} 4$ Longer exposure to family business leads to preferring family business succession over employment and founder career alternatives (Carr and Sequeira 2007; Morris, Williams, and Nel, 1996).

Another factor, which importantly influences the succession process and successor's career decision as a crucial part of it, is heir's ability to take the control over family firm. Successor's business skills play an important role since lack of skills may easily lead to the refusal of the position (De Massis, Chua, and Chrisman 2008). Previous studies among students deriving from family businesses showed that offspring's intention to join the family business is significantly related to individual skills and abilities (Stavrou 1999). In their study, Morris, Williams, and Nel (1996) also concluded that heir's formal level of education and training as well as self-perception of his or her preparation level at the time of succession has a significant influence on the succession process itself. In this context, the concept of entrepreneurial self-efficacy should be mentioned, especially in relation to heir's level of education and skill training, which should concentrate more on capabilities like innovation and risk-taking management and less on technical entrepreneurial skills (Chen, Greene, and Crick 1998). Recent studies confirmed a positive relationship be- 
tween self-efficacy and entrepreneurial intention since individual's belief on his or her abilities positively affects the entrepreneurial intention (Farrukh et al. 2017; Owoseni 2014).

All these factors are contributing to the positive image of the family firm in the eyes of the heir. The succession process is generally more likely to succeed if children have a positive image of the family firm. In such case, participation in family business is viewed more as an opportunity and not that much as an obligation. With the goal of long term survivor, family business has to produce motivated heirs with highly developed entrepreneurial skills (Kleiman and Peacok 1996).

H5 Students with more positive perception of their own entrepreneurial skills will prefer founding own new business over the succession and succession over the employment (De Massis, Chua, and Chrisman 2008; Morris, Williams, and Nel 1996; Stavrou, 1999).

\section{Methods}

Our data originates from GUesss 2014 survey data collection with around 109.000 student respondents from 34 countries. The survey collected data anonymously on-line. With the goal of preventing multiple responses bias we used IP identification based questionnaire. In the absence of general family business definition we relied on the definition of Barnes and Hershon (1976) according to which the majority of shares in family business is owned by one or more members of the same family. Consequently, 23.485 European students with family business background from 18 countries were sampled from data set (Great Britain, Germany, Luxemburg, Netherlands, Switzerland, Austria, Belgium, Denmark, Spain, Finland, France, Italy, Portugal, Slovenia, Romania, Poland, Estonia and Hungary).

Respondents were answering direct questions about the possible ownership of mother, father or both parents. Students, with family business background, who already owned their own business, were also excluded from the study, since they could have been a potential source of survivor bias in retrospective studies (Davidsson 2004; Gartner 1989). Our respondents were asked about their career choice immediately after their studies and five years after that period. They had four possibilities to choose from: 'an employee', 'an entrepreneur', 'a successor' or 'I don't know yet'. The option 'I don't know yet' allowed avoiding forced decisions. Only student with family business experience are included in the study. After all necessary 
TABLE 1 Sample Structure

\begin{tabular}{llrrrrr}
\hline Item & & \multicolumn{2}{c}{ Immed. after studies } & & \multicolumn{2}{c}{ years after studies } \\
\cline { 3 - 3 } \cline { 6 - 7 } & & $n$ & $\%$ & $n$ & $\%$ \\
\hline Career choice & Employee & 3450 & 85.9 & & 1660 & 45.9 \\
& Founder & 268 & 6.7 & 1444 & 39.9 \\
& Successor & 298 & 7.4 & 515 & 14.2 \\
\hline Gender & Man (ref) & 1763 & 43.9 & 1599 & 44.2 \\
& Woman & 2253 & 56.1 & 2020 & 55.8 \\
\multirow{2}{*}{ Entrep. education } & No (ref) & 1844 & 45.9 & 1689 & 46.7 \\
& Yes & 2172 & 54.1 & 1930 & 53.3 \\
\hline Valid & & 4016 & 100.0 & 3619 & 100.0 \\
\hline
\end{tabular}

reductions 4.016 students were included in the study for the period immediately following their studies and 3.619 students for the period of five years after finishing their studies. The number of participants differs due to undecided individuals, which were excluded. The principal demographics and responds about basic career intentions are displayed in table 1.

Since our dependant variable is categorical with three possible solutions (employee, founder, successor), we used multinomial logistic regression, which we found as the most appropriate statistic method. In our paper we investigate succession so it is always the reference category when interpreting our regression results. We constructed two regression models. One for the period immediately after finishing the study and one for the period five years after finishing the study. The second option is forcing respondents to concentrate on both periods precisely when answering (Zellweger, Sieger, and Halter 2011). Besides, an entrepreneur typically works elsewhere for five years in average, before engaging in a new start-up (Brockhaus and Horwitz 1986).

Our first two independent variables are autonomy (three items: 'freedom', 'independence' and 'to be your own boss') and selfrealization (three items: 'to realize your dream', 'to create something' and 'to take advantage of your creative needs'). Both are captured using 7-point Likert scale. We used items already tested in some earlier studies (Souitaris, Zerbinati, and Al-Laham 2007). We measured self-assessed entrepreneurial skills as our third independent variable using 8 items. Students indicated their level of competence in performing eight entrepreneurial tasks: (1) identifying new business opportunities; (2) creating new products and services; (3) applying my personal creativity; (4) managing innovation within a firm; (5) 
TABLE 2 Pearson Correlations: Immediately After Studies

\begin{tabular}{|c|c|c|c|c|c|c|c|c|c|}
\hline Item & (1) & (2) & (3) & (4) & (5) & (6) & (7) & (8) & (9) \\
\hline (1) & 1 & -0.022 & $0.036^{*}$ & $0.038^{* *}$ & $-0.037^{*}$ & $0.039^{* *}$ & -0.029 & $0.037^{*}$ & $-0.044^{* *}$ \\
\hline (2) & -0.022 & 1 & $0.448^{* *}$ & $-0.128^{* *}$ & $0.324^{* *}$ & 0.024 & 0.015 & $0.167^{* *}$ & $0.198^{* *}$ \\
\hline (3) & $0.036^{*}$ & $0.448^{* *}$ & 1 & $-0.143^{* *}$ & $0.370^{* *}$ & $0.054^{* *}$ & 0.009 & $0.125^{* *}$ & $0.128^{* *}$ \\
\hline (4) & $0.038^{* *}$ & $-0.128^{* *}$ & $-0.143^{* *}$ & 1 & $-0.210^{* *}$ & $-0.056^{* *}$ & -0.023 & $-0.038^{*}$ & $-0.108^{* *}$ \\
\hline (5) & $-0.037^{*}$ & $0.324^{* *}$ & $0.370^{* *}$ & $-0.210^{* *}$ & 1 & 0.013 & $0.065^{* *}$ & $0.197^{* *}$ & $0.152^{* *}$ \\
\hline (6) & $0.039^{* *}$ & 0.024 & $0.054^{* *}$ & $-0.056^{* *}$ & 0.013 & 1 & $-0.250^{* *}$ & $-0.097^{* *}$ & $0.033^{*}$ \\
\hline (7) & -0.029 & 0.015 & 0.009 & -0.023 & $0.065^{* *}$ & $-0.250^{* *}$ & 1 & $0.179^{* *}$ & $0.097^{* *}$ \\
\hline (8) & $0.037^{*}$ & $0.167^{* *}$ & $0.125^{* *}$ & $-0.038^{*}$ & $0.197^{* *}$ & $-0.097^{* *}$ & $0.179^{* *}$ & 1 & $0.164^{* *}$ \\
\hline (9) & $-0.044^{* *}$ & $0.198^{* *}$ & $0.128^{* *}$ & $-0.108^{* *}$ & $0.152^{* *}$ & $0.033^{*}$ & $0.097^{* *}$ & $0.164^{* *}$ & 1 \\
\hline
\end{tabular}

Notes Column/row readings are as follows: (1) gender, (2) autonomy, (3) selfrealization, (4) entrepreneurial education, (5) skills, (6) age working for $\mathrm{FB},(7)$ time working for FB, (8) feelings toward FB, (9) career decision.

TABLE 3 Pearson Correlations: Five Years After Studies

\begin{tabular}{lrrrrrrrrr}
\hline Item & $(1)$ & $(2)$ & $(3)$ & $(4)$ & $(5)$ & $(6)$ & $(7)$ & $(8)$ & $(9)$ \\
\hline$(1)$ & 1 & -0.009 & $0.040^{*}$ & 0.025 & -0.031 & $0.042^{*}$ & -0.020 & $0.035^{*}$ & $-0.060^{* *}$ \\
$(2)$ & -0.009 & 1 & $0.451^{* *}-0.124^{* *}$ & $0.326^{* *}$ & 0.026 & 0.011 & $0.167^{* *}$ & $0.272^{* *}$ \\
$(3)$ & $0.040^{*}$ & $0.451^{* *}$ & 1 & $-0.139^{* *}$ & $0.367^{* *}$ & $0.058^{* *}$ & 0.006 & $0.132^{* *}$ & $0.166^{* *}$ \\
$(4)$ & 0.025 & $-0.124^{* *}$ & $-0.139^{* *}$ & 1 & $-0.202^{* *}$ & $-0.056^{* *}$ & -0.024 & $-0.042^{*}$ & $-0.116^{* *}$ \\
$(5)$ & -0.031 & $0.326^{* *}$ & $0.367^{* *}$ & $-0.202^{* *}$ & 1 & 0.020 & $0.058^{* *}$ & $0.200^{* *}$ & $0.225^{* *}$ \\
$(6)$ & $0.042^{*}$ & 0.026 & $0.058^{* *}-0.056^{* *}$ & 0.020 & 1 & $-0.248^{* *}$ & $-0.076^{* *}$ & $0.047^{* *}$ \\
$(7)$ & -0.020 & 0.011 & 0.006 & -0.024 & $0.058^{* *}-0.248^{* *}$ & 1 & $0.175^{* *}$ & $0.050^{* *}$ \\
$(8)$ & $0.035^{*}$ & $0.167^{* *}$ & $0.132^{* *}-0.042^{*}$ & $0.200^{* *}$ & $-0.076^{* *}$ & $0.175^{* *}$ & 1 & $0.235^{* *}$ \\
$(9)$ & $-0.060^{* *}$ & $0.272^{* *}$ & $0.166^{* *}-0.116^{* *}$ & $0.225^{* *}$ & $0.047^{* *}$ & $0.050^{* *}$ & $0.235^{* *}$ & 1 \\
\hline
\end{tabular}

NотеS Column/row readings are as follows: (1) gender, (2) autonomy, (3) selfrealization, (4) entrepreneurial education, (5) skills, (6) age working for FB, (7) time working for FB, (8) feelings toward FB, (9) career decision.

being a leader and communicator; (6) building up a professional network; (7) commercializing a new idea or development; and (8) successfully managing a business. The eight items were developed from previous studies of self-efficacy and innovation (Chen, Greene, and Crick 1998; Zhao 2005; Kickul et al. 2009; DeNoble, Ehrlich, and Singh 2007). The measuring scale was from 1 (very low competence) to 7 (very high competence). Our fourth and fifth independent variables are continuous since students were directly asked when (at what age) and for how long (in months) they had been actively engaged in family business.

We introduced three control variables in the model: gender, entrepreneurial education and positive or negative feelings towards 
family business. Gender and entrepreneurial education are introduced as categorical values. Participants were asked if they have attended at least one subject, which included entrepreneurial theory and/or skills. We captured students feeling towards their family business with five items measured using 7-point Likert scale (attachment, feelings, tradition, importance of keeping the firm in the family and having a deep insight into business).

Pearson correlations results are shown in tables 2 and 3 . Since all correlations are well below the marginal value of 0.6 , shared variance is not the problem (Hair et al. 2010). We calculated variance inflation factor (VIF) for each independent variable. It never exceeds 1.4 which is well below the marginal value of 3.0 and it is safe to expect that multicolinearity does not seem to be a problem in our model (Hair et al. 2010). Our independent variables are confirmed to be empirically distinct since one factor solution from Harman's single-factor test accounted for $33.59 \%$ of total variance. As such, it didn't reach the threshold of 50\% (Hair et al. 2010).

\section{Results}

Our regression model results for both periods observed are presented in table 4. Looking at motivational factors included in the model, we may conclude that higher level of craving autonomy leads more to succession compared to employment. Calculated coefficients are noticeably high for both periods $(B=-0.463$ and $B=-0.353)$. We also see that students intend to engage into a new start-up rather than taking over a family firm $(B=0.009$ and $B=0.197)$. Relaying on this conclusions we can confirm our first hypotheses for both investigated time-periods. The motive of self-realization results in slightly differentiated picture. We can completely confirm our second hypotheses for the period following immediately after studies, since potential heirs with higher desire for self-realization will prefer to continue family business tradition rather than find an employment $(B=-0.049)$. On the other hand, they also prefer a new start-up to succession $(B=0.127)$. For the period of five years after finishing their studies, the participants prefer both alternatives over the succession $(B=0.100$ and $B=0.388)$. This only partly confirms our second hypotheses which claimed, that higher level of perceived importance of self-realization result in preferring founding own new business over the succession and succession over the employment.

The older the heir is when firstly exposed to family business experience, the higher is the probability for succession career decision 
TABLE 4 Regression Models Results

\begin{tabular}{|c|c|c|c|c|c|}
\hline \multicolumn{2}{|c|}{ Model coefficients } & \multicolumn{2}{|c|}{ Immed. after studies } & \multicolumn{2}{|c|}{5 years after studies } \\
\hline \multirow[t]{9}{*}{ Employee } & Intercept & 9.445 & 0.000 & $7 \cdot 535$ & 0.000 \\
\hline & Autonomy & -0.463 & 0.000 & -0.353 & 0.000 \\
\hline & Self-realization & -0.049 & 0.471 & 0.100 & 0.048 \\
\hline & Skills & -0.145 & 0.043 & -0.240 & 0.000 \\
\hline & Age working for F B & -0.054 & 0.002 & -0.059 & 0.000 \\
\hline & Time working for FB & -0.009 & 0.000 & -0.002 & 0.441 \\
\hline & Feelings toward FB & -0.403 & 0.000 & -0.549 & 0.000 \\
\hline & Gender (mail) & -0.249 & 0.048 & -0.368 & 0.001 \\
\hline & Entrep. education & -0.448 & 0.000 & -0.201 & 0.064 \\
\hline \multirow[t]{9}{*}{ Founder } & Intercept & 1.183 & 0.151 & 0.316 & 0.517 \\
\hline & Autonomy & 0.009 & 0.926 & 0.197 & 0.001 \\
\hline & Self-realization & 0.127 & 0.195 & 0.388 & 0.000 \\
\hline & Skills & 0.149 & 0.136 & 0.095 & 0.118 \\
\hline & Age working for FB & -0.052 & 0.026 & -0.036 & 0.019 \\
\hline & Time working for $\mathrm{FB}$ & 0.001 & 0.840 & -0.001 & 0.659 \\
\hline & Feelings toward FB & -0.435 & 0.000 & -0.524 & 0.000 \\
\hline & Gender (mail) & 0.057 & 0.741 & -0.120 & 0.264 \\
\hline & Entrep. education & 0.092 & 0.605 & 0.304 & 0.005 \\
\hline
\end{tabular}

compared to both other alternatives in both periods, which we observed $(B=-0.054 ; B=-0.052 ; B=-0.059 ; B=-0.036)$. Based on these results, we can completely reject our third hypotheses based on which, older the heir is when exposed to family business for the first time, higher should be the preference for employment or founding own new business over the succession. Highly significant results in this part surprised us, since they seem to oppose general believe that exposure in younger age positively influences succession intention.

We found out that duration of an active exposure to family business does not have any significant influence on heir's career choice. Our results are not statistically significant, with the exception of coefficient, which is defining the correlation between succession option and the employment alternative. The longer the time of involvement in family firm, the higher the possibility for succession compared to employment straight after the studies are completed $(B=$ -0.009). We can confirm only this part of our fourth hypothesis. Still the values of all coefficients, including the one mentioned above, are very low $(B=-0.009 ; B=-0.002 ; B=0.001 ; B=-0.001)$. As such, they 
have a low impact on the career decision in our model (dependant variable).

In both periods, students with higher developed entrepreneurial skills prefer to take over family business if confronted with employment alternative $(B=-0.145 ; B=-0.240)$. They also prefer starting of a new company to succession $(B=0.149 ; B=0.095)$. Still, we have to emphasize that our results are not statistically significant when comparing founder and successor career opportunities. Due to this fact we can only partly confirm our fifth hypothesis according to which students with more positive perception of their own entrepreneurial skills should prefer founding own new business over the succession and succession over the employment.

Measuring feelings towards family business ended up with highly statistically significant results. Like expected, students with family business background and higher level of positive feelings towards family firm, will prefer succession career to both alternatives $(B=-$ $0.403 ; B=-0.549 ; B=-0.435 ; B=-0.524)$. Model coefficients are very high in this part, which indicates that this variable should be a part of similar models when investigating career decision process.

Our control variable for gender emerged as statistically significant when comparing employment career with succession alternative. Male students, compared to females, will more likely choose succession over employment in both observed time-periods $(B=-$ $0.249 ; B=-0.368)$. We detected a difference when comparing founder and succession alternative, yet without statistically significant results. Males, compared to females, will more likely start-up a new company than take over a family business in the period immediately after their studies $(B=0.057)$. Five years after that, males will more likely choose succession over foundation $(B=-0.120)$.

Students without any kind of entrepreneurial education will prefer succession career to employment in both observed periods. Coefficient is high $(B=-0.448)$ and highly statistically significant $(p<$ o.001) for the period immediately after studies. Regardless the lack of entrepreneurial education, they will also rather choose to start-up a new company despite the opportunities they could have in family firm. The coefficient is noticeably high $(B=0.304)$ and statistically significant $(p=0.005)$ for the period five years after the studies.

\section{Discussion and Implications}

Our paper contributes to explaining and better understanding the career trilemma which stands in front of students with family business background upon finishing their studies. We investigated career 
decision patterns of students in European countries in relation to motivation for autonomy and self-realization, entrepreneurial skills and exposure to family firm in the form of active involvement. With some very interesting results, we believe that the study substantially upgrades family business succession literature and gives some new perspectives and guides for future researches of career decision making process. Our study differentiates entrepreneurial intention from family business succession intention. As such it follows the calls for closing the research gap on this area (Zapkau, Schwens, and Kabst 2017).

Potential heirs, driven by high level of autonomy motive will definitely choose succession rather than employment career. Despite frequently mentioned potential obstacles from the parent's side, they still feel they can be more autonomous in family firm than elsewhere if they take the role of an employee. This finding is in line with previous research results which claimed that family support significantly influences children's entrepreneurial intention (Shen, Osorio, and Rutgers 2017; Farrukh et al. 2017). We also saw that immediately after the studies, they don't make a difference between level of autonomy gained as a successor or as a founder. Five years later they will prefer to start-up a new business instead of succession. We could speculate that they are willing to try for a few years and check if they can reach desired level of autonomy within family firm. This line of conclusion adequately follows previous studies which founded out that family members want to learn from family business before starting their own firm (Tarling, Jones, and Murphy 2016). The motive of self-realization gave us similar results. We detected a different result only when comparing employment and succession alternatives five years after the study. Students with stronger desire for self-realization would find a job rather than take over a family business in that period. It is possible that the reason for this is gaining experience in stabile environment provided inside a family business. After obtaining the adequate knowledge and skills, heirs will seek self-realization opportunities elsewhere as employees or with new start-ups, which confirms the results from previous studies (Murphy and Lambrechts 2015; Tarling, Jones, and Murphy 2016). These findings should serve as guidelines for parents when planning a succession process. Both motives emerged as very important in the decision making process, so parents should carefully consider how to make it possible for children to reach their goals.

Our results show that the older the heir is when actively engaged into family business, the more probably he/she will decide for a suc- 
cession career compared to both other career alternatives (employment or new start-up). This finding is, by all means something to think about since it doesn't support previous findings which claimed that early exposure to experience in family business will affect family member's intentions and attitudes (Dyer and Handler 1994) and, that family members are most strongly involved as young individuals (Klyver 2007). It does still however support previous findings that early socialization in family firm forms individual's entrepreneurial values and attitudes (Light and Bonachich 1991). Our result is also supporting the fact that helping in family firm develops important entrepreneurial and general life skills (Fuligni and Telzer 2013). We can't say that our finding completely opposes to previous researches since the design of our study was driven by existing data set and results we provided are not directly comparable with previous studies. However, we think that our paper indicates the necessity for further research of the topic similarly like some other recent studies concluded (Murphy and Lambrechts 2015).

Based on previous studies, researchers expected that length of exposure to family business may significantly influence career decision (Morris, Williams, and Nel 1996). Our study importantly contributes to this specific question by resulting with negative answer in case of students with family business background. We still have to keep in mind, that we are investigating a very narrow group of young people confronted with a specific trilemma. Yet, our results are very clear. The length of engagement in family firm doesn't affect heir's career decision. Our conclusion is in line with previous studies which concluded that long period of involvement in family business may limit career choice opportunities in critical period (Schröder and Schmitt-Rodermund 2013). This finding represents a useful and practical guideline for parents and educational institutions. It is important to gain some experience, however, longer experience does not necessarily affect future career decision. Exposure to family business is something that seems to occur spontaneously when speaking about potential heirs. This fact may also represent a pleasure since long-term well being of family business may oppose to heir's personal interests (Murphy and Lambrechts 2015). Our findings indicate that this is not likely to be a considerable problem for career decision making process at least when we analyze the length of active engagement (working for family firm). There are other influential factors, to which a potential heir is constantly exposed in family with family business, like lack of parental time, exposure to business problems, parental stress and many more. In our 
opinion, these factors should be precisely modelled in future studies. From the implication perspective our result implies that it is very important to include potential successor as much as possible into family business during the period of heir's university study. In our opinion entrepreneurial parents should follow this guideline regardless the amount of previous successor's engagement in the family firm.

Previous researchers already confirmed the correlation between entrepreneurial skills and self-competence (Morris, Williams, and Nel 1996; Farrukh et al. 2017). We can confirm that higher level of entrepreneurial skills surely gives stronger feeling of self-competence which further results in preferring succession to employment and a new start-up to succession. This is an expected result which confirms existing concepts and previous findings (Chen, Greene, and Crick 1998; Farrukh et al. 2017). It is of great importance for parents, educational institutions and governments providing support environment for businesses. Our control variable which included entrepreneurial education in the model, gave similar results, which is also expected. Nowadays, when we have already recognized the importance of SME for national economy, it is crucial to provide high level of entrepreneurial knowledge and skills to young generation. It is of the best interest of all parties. Parents may think, that providing more knowledge and developing entrepreneurial skills will lead heirs to select a, for them unwanted, independent path but this is not necessarily true. In our opinion, it is crucial to recognize that not developing entrepreneurial skills is surely the least desirable choice. There are many factors influencing potential heir's career decision. Highly developed entrepreneurial skills should be recognized as a precondition and shouldn't be used as a tool for influencing heir's decision. However, parents should become aware of the results of this study and try to gain children's confidence and affection for family firm using other methods, since their goal should always be to assure the long-term survival of a family firm.

Continuing our thinking from previous paragraph, we should have a look at feelings towards family business. In our model this variable reached highly statistical significance in favour of family business. It may well be one of the important tools for gaining heir's affection mentioned beforehand. This result is in accordance with naturally engrained need for helping the family, which has significant implications for career decision according to previous studies (Murphy and Lambrechts 2015). Building positive feelings towards family business should be a continuous process. Parents, as role models, surely have the main role in this process. Having in mind our previ- 
ously discussed results about the age of heir's engagement into family business, parents should know that it is never too early and it is never too late. They should start involving young children in family business as soon as possible and they should never stop until career decision is already, not only made, but implemented.

When observing entrepreneurial education, we learned that entrepreneurial education doesn't increase the entrepreneurial intention level. This finding is in line with previous studies which confirmed that entrepreneurial education by itself is not a sufficient influencing factor. It has to be understood more as a mediating factor which influences personal traits and psychological characteristics of an individual (do Paço et al. 2015). Similarly, Kusmintarti et al. (2016) confirmed that entrepreneurial education is an indirect factor which influences student's entrepreneurial skills, risk taking propensity and creativity.

\section{Limitations of the Research}

Our research is partly limited by the fact that we used an existing dataset. This disabled us to design a model which could be more comparable with the results of previous studies. GUEsss survey used self-assessed measures, which is much easier and cheaper method for gaining information but could be biased. However, we limited this problem by using multi-item Likert scales and by guaranteeing strict confidentiality to our participants.

The study is also limited by the fact that Guesss survey doesn't provide information about job access, which could be a factor influencing heir's career decision. This is the main reason why we limited our study to European countries where we expect comparable conditions regarding the issue all over the region.

\section{Future Studies}

Our study significantly advanced the understanding of successor's previous entrepreneurial engagement in family firm influence on his or her entrepreneurial intention but still left opened some important questions linked to family business succession process. The age and the length of potential heir's active involvement into family business as well as informal exposure to family business environment should be investigated using more complex models. Further studies should strive for better explaining the influential factors, deriving from family environment in one general multilevel model. Our suggestion is further grounded by the fact that feelings towards family business variable emerged as highly significant in our model. 
Since some of our results are in conflict with previous studies, we recommend replication studies with the goal of resolving these conflicts. Future studies should put a stronger emphasis on the specific trilemma confronted by the students with family business background and clearly distinguish between new start-up and succession direction within entrepreneurial career possibilities.

With further qualitative research the reasons behind the influence of different variables on target group career choice intentions should be analyzed. Qualitative studies do not allow establishing significant influences but they do offer a possibility of better understanding the family business environment which makes potential successor career decision more complicated. This kind of qualitative research could be used as a base point for building a much more predictive multilevel quantitative model targeting the issue of succession. Future researcher should also consider analyzing different geographical regions and cultural environments.

\section{References}

Aldrich, H. E., and J. E. Cliff. 2003. 'The Pervasive Effects of Family on Entrepreneurship: Toward a Family Embeddedness Perspective.' Journal Of Business Venturing 18 (5): 573-96.

Altinay, L., M. Madanoglu, R. Daniele, and C. Lashley. 2012. 'The Influence of Family Tradition and Psychological Traits on Entrepreneurial Intention.' International Journal of Hospitality Management 31 (2): 489-99.

Bandura, A. 1977. Social Learning Theory. Englewood Cliffs, NJ: PrenticeHall.

Barba-Sánchez, V., and C. Atienza Sahuquillo. 2012. 'Entrepreneurial Behavior: Impact of Motivation Factors on Decision to Create a New Venture.' Investigaciones Europeas de Dirección y Economía de la Empresa 18:132-38.

Barnes, L. B., and S. A. Hershon. 1976. 'Transferring Power in the Family Business.' Harvard Business Review 54 (4): 105-14.

Basco, R., and M. J. P. Rodríguez. 2009. 'Studying the Family Enterprise Holistically: Evidence for Integrated Family and Business Systems.' Family Business Review 22 (1): 82-95.

Bosma, N., J. Hessels, V. Schutjens, M. Van Praag, and I. Verheul. 2012. 'Entrepreneurship and Role Models.' Journal of Economic Psychology 33 (2): 410-24.

Brockhaus, R. H., and P. S. Horwitz 1986. 'The Psychology of the Entrepreneur.' In The Art and Science of the Entrepreneurship, edited by D. L. Sexton and R. W. Smilor, 25-48. Cambridge: Ballinger.

Carr, J. C., and J. M. Sequeira. 2007. 'Prior Family Business Exposure as Intergenerational Influence and Entrepreneurial Intent: A The- 
ory of Planned Behavior Approach.' Journal of Business Research 60 (10): 1090-1098.

Carter, N., W. B. Gartner, K. G. Shaver, and E. J. Gatewood. 2003. 'The Career Reasons of Nascent Entrepreneurs.' Journal of Business Venturing 18 (1): 13-39.

Chen, C. C., P. G. Greene, and A. Crick. 1998. 'Does Entrepreneurial Self-Efficacy Distinguish Entrepreneurs from Managers?' Journal of Business Venturing 13 (4): 295-316.

Chlosta, S., H. Patzelt, S. B. Klein, and C. Dormann. 2012. 'Parental Role Models and the Decision to Become Self-Employed: The Moderating Effect of Personality.' Small Business Economics 38 (1): 121-38.

Claire, L., and A. A. Perryman. 2016. 'Where's Waldo? The Search for Entrepreneurial Role Models.' Journal of Entrepreneurship Education 19 (1): 91-102.

Davidsson, P. 2004. Researching Entrepreneurship. New York: Springer.

De Massis, A., J. H. Chua, and J. J. Chrisman. 2008. 'Factors Preventing Intra-Family Succession.' Family Business Review 21 (2): 183-99.

DeNoble, A., S. Ehrlich, and G. Singh. 2007. 'Toward the Development of a Family Business Self-Efficacy Scale.' Family Business Review 20 (2): 127-40.

do Paço, A., J. M. Ferreira, M. Raposo, R. G. Rodrigues, and A. Dinis. 2015. 'Entrepreneurial Intentions: Is Education Enough?' International Entrepreneurship and Management Journal 11 (1): 57-75.

Dorożyńska, A., and T. Dorożyński. 2015. 'Human Capital and FDI in Central and Eastern Europe.' Managing Global Transitions 13 (2): 151-70.

Dyer, G. W. 1992. The Entrepreneurial Experience: Confronting Career Dilemmas of the Start-Up Executive. San Francisco, cA: Jossey-Bass.

Dyer, G. W., and W. Handler. 1994. 'Entrepreneurship and Family Business.' Entrepreneurship Theory and Practice 19 (1): 71-83.

Eddleston, K. A., F. W. Kellermanns, and R. Sarathy. 2008. 'Resource Configuration in Family Firms: Linking Resources, Strategic Planning and Technological Opportunities to Performance.' Journal of Management Studies 45 (1): 26-50.

Edelman, L. F., C. G. Brush, T. S. Manolova, and P. G. Green. 2010. 'Start-up Motivations and Growth Intentions of Minority Nascent Entrepreneurs.' Journal of Small Business Management 48 (2): 17496.

Farrukh, M., A. A. Khan, M. S. Khan, S. R. Ramzani, and B. S. A. Soladoye. 2017. 'Entrepreneurial Intentions: The Role of Family Factors, Personality Traits and Self-Efficacy.' World Journal of Entrepreneurship Management and Sustainable Development 13(4): 303-17.

Fuligni, A. J., and E. H. Telzer. 2013. 'Another Way Family Can Get in the Head and Under the Skin: The Neurobiology of Helping the Family.' Child Development Perspectives 7 (3): 138-42. 
Gartner, W. B. 1989. 'Some Suggestions for Research on Entrepreneurial Traits and Characteristics.' Entrepreneurship: Theory \& Practice 14 (1): 27-37.

Gibson, D. E. 2004. 'Role Models in Career Development: New Directions for Theory and Research.' Journal of Vocational Behavior 65 (1): $134^{-56}$.

Hair, J. F., W. C. Black, B. J. Babin, and R. E. Anderson. 2010. Multivariate Data Analysis. 7th ed. Upper Saddle River, NJ: Pearson Education.

Kickul, J., L. K. Gundry, S. D. Barbosa, and L. Whitcanack. 2009. 'Intuition Versus Analysis' Testing Differential Models of Cognitive Style on Entrepreneurial Self-Efficacy and the New Venture Creation Process.' Entrepreneurship Theory and Practice 33 (2): 439-53.

Kim, P. H., H. E. Aldrich, and L. A. Keister. 2006. 'Access (Not) Denied: The Impact of Financial, Human, and Cultural Capital on Entrepreneurial Entry in the United States.' Small Business Economics 27 (1): 5-22.

Kleiman, R., and E. Peacok. 1996. 'Family Businesses as an Economic Phenomenon.' Michigan Family Review 2 (2): 93-101.

Klyver, K. 2007. 'Shifting Family Involvement During the Entrepreneurial Process.' Journal of Entrepreneurial Behavior \& Research 13 (5): 258-77.

Kolvereid, L. 1996. 'Organizational Employment versus Self-Employment: Reasons for Career Choice Intentions.' Entrepreneurship: Theory and Practice 20 (3): 23-31.

Kusmintarti, A., A. Thoyib, G. Maskie, and K. Ashar. 2016. 'Entrepreneurial Characteristics as a Mediation of Entrepreneurial Education Influence on Entrepreneurial Intention.' Journal of Entrepreneurship Education 19 (1): 24-37.

Le Breton-Miller, I., D. Miller, and L. P. Steier. 2004. 'Toward an Integrative Model of Effective ғов Succession.' Entrepreneurship Theory and Practice 28 (4): 305-28.

Light, I., and E. Bonachich. 1991. Immigrant Entrepreneurs: Koreans in Los Angeles, 1965-1982. San Francisco: University of California Press.

Maksimenko, S., and L. Serdiuk. 2016. 'Psychological Potential of Personal Self-realization.' Social Welfare Interdisciplinary Approach 6(1): 93-100.

Maslow, A. 1954. Motivation and Personality. New York: Harper \& Row.

Menaghan, E. G., and T. L. Parcel. 1995. 'Social Sources of Change in Children's Home Environments: The Effects of Parental Occupational Experiences and Family Conditions.' Journal of Marriage and Family 57 (1): 69-84.

Morris, M. H., R. W. Williams, and D. Nel. 1996. 'Factors Influencing Family Business Succession.' International Journal of Entrepreneurial Behavior \& Research 2 (3): 68-81. 
Murphy, L., and F. Lambrechts. 2015. 'Investigating the Actual Career Decisions of the Next Generation: The Impact of Family Business Involvement.' Journal of Family Business Strategy 6 (1): 33-44.

Nicolau, N., S. Shane, L. Cherkas, and T. D. Spector. 2008. 'The Influence of Sensation Seeking in the Heritability of Entrepreneurship.' Strategic Entrepreneurship Journal 2 (1): 7-21.

Owoseni, O. O. 2014. 'The Influence of Some Personality Factors on Entrepreneurial Intentions.' International Journal of Business and Social Science 5 (1): 278-84.

Ozaralli, N., and N. K. Rivenburgh. 2016. 'Entrepreneurial Intention: Antecedents to Entrepreneurial Behavior in the U.S.A. and Turkey.' Journal of Global Entrepreneurship Research 6 (1): 1-32.

Renko, M., G. K. Kroeck, and A. Bullough. 2012. 'Expectancy Theory and Nascent Entrepreneurship.' Small Business Economics 39(3): 667-84.

Schröder, E., and E. Schmitt-Rodermund. 2013. 'Antecedents and Consequences of Adolescents' Motivations to Join the Family Business.' Journal of Vocational Behavior 83 (3): 476-85.

Shen, T., A. E. Osorio, and A. S. Rutgers. 2017. 'Does Family Support Matter? The Influence of Support Factors on Entrepreneurial Attitudes and Intentions of College Students.' Academy of Entrepreneurship Journal 23 (1): 24-43.

Souitaris, V., S. Zerbinati, and A. Al-Laham. 2007. 'Do Entrepreneurship Programmes Raise Entrepreneurial Intention of Science and Engineering Students? The Effect of Learning, Inspiration and Resources.' Journal of Business Venturing 22 (4): 566-91.

Stavrou, E. T. 1999. 'Succession in Family Businesses: Exploring the Effects of Demographic Factors on Offspring Intentions to Join and Take over the Business.' Journal of Small Business Management 37 (3): 43-61.

Tarling, C., P. Jones, and L. Murphy. 2016. 'Influence of Early Exposure to Family Business Experience on Developing Entrepreneurs.' Education + Training 58 (7-8): 733-50.

van Geldern, M., and P. Jansen. 2006. 'Autonomy as a Start-Up Motive.' Journal of Small Business and Enterprise Development 13 (1): 23-32.

Waterman, A. S., S. J. Schwartz, E. Goldbacher, H. Green, C. Miller, and S. Philip. 2003. 'Predicting the Subjective Experience of Intrinsic Motivation: The Roles of Self-Determination, the Balance of Challenges and Skills, and Self-Realization Values.' Personality and Social Psychology Bulletin 29 (11): 1447-458.

Zapkau, F. B., C. Schwens, and R. Kabst. 2017. 'The Role of Prior Entrepreneurial Exposure in the Entrepreneurial Process: A Review and Future Research Implications.' Small Business Management 55(1): 56-86.

Zellweger, T. M., F. W. Kellermanns, J. J. Chrisman, and J. H. Chua. 2012. 'Family Control and Family Firm Valuation by Family ceos: The Im- 
portance of Intentions for Transgenerational Control.' Organization Science 23 (3): 851-68.

Zellweger, T., P. Sieger, and F. Halter. 2011. 'Should I Stay or Should I Go? Career Choice Intentions of Students with Family Business Background.' Journal of Business Venturing 26 (5): 521-36.

Zhao, F. 2005. 'Exploring the Synergy between Entrepreneurship and Innovation.' International Journal of Entrepreneurial Behavior \& Research 11 (1): 25-41.

This paper is published under the terms of the AttributionNonCommercial-NoDerivatives 4.0 International (CC BY-NC-ND 4.0) License (http://creativecommons.org/licenses/by-nc-nd/4.o/). 